\title{
Spectrum of giant cell tumor
}

\author{
Parth Sachapara ${ }^{1}$, Jay Date ${ }^{2 *}$, Deepak Naikwade ${ }^{3}$, Pandurang Daule ${ }^{4}$ \\ 1,2Junior Resident III, ${ }^{3}$ Professor \& HOD, ${ }^{4}$ Associate Professor, Department of Orthopaedics, Dr Vithalrao Vikhe Patil Medical College \& \\ Hospital, Ahmednagar, Maharashtra, INDIA. \\ Email: dr.parth.s@gmail.com
}

Abstract Background: Giant cell tumor(GCT) of bone is a commonly occurring, locally aggressive benign tumor which has high recurrence rate. GCT represents $5 \%$ of all primary bone tumors. The most common location for GCT as per their frequency are- distal end of femur, proximal end of tibia, distal end of radius, proximal humerus and vertebral body of sacrum. Epiphysis of long bones is the classic site of GCT. Along epiphysis, extension in metaphysis or diaphysis may be seen. Primary and recurrent GCT is typically benign. Malignant transformation is seen in $<1 \%$ of all cases and patients are a decade older than benign ones. Materials and method: A total number of 20 cases of Giant Cell Tumors of bone and tendon sheath were studied. Clinical history and examination findings were studied from hospital record section. Results: Total 20 cases of GCT were studied. Out of these, 15 cases were seen in bone and 5 cases in tendon sheath. Most common site in the present study is distal end of femur. Most common age group for GCT was 15-30 years. Female predominance was noted in this study. In all GCT 1-year post-operative period was uneventful, no recurrence was found. Conclusion: GCT of bone and tendon sheath is typically benign tumor. Surgically excision with bone grafting and adjuvant therapy can cure the lesion.

Key Words: GCT, Giant cell tumor of bone, Benign Tumor, GCT of tendon sheath.

\section{*Address for Correspondence:}

Dr Jay Date, Junior Resident III, Department of Orthopaedics, Dr Vithalrao Vikhe Patil Medical College \& Hospital, Ahmednagar, Maharashtra, INDIA.

Email: xxxx@gmail.com

Received Date: 20/03/2020 Revised Date: 15/05/2020 Accepted Date: 11/06/2020

DOI: https://doi.org/10.26611/1031511

This work is licensed under a Creative Commons Attribution-NonCommercial 4.0 International License. (cc)) BY-No

\begin{tabular}{|l|l|}
\hline \multicolumn{2}{|c|}{ Access this article online } \\
\hline Quick Response Code: & Website: \\
& www.medpulse.in \\
& \\
\hline
\end{tabular}

\section{INTRODUCTION}

Giant cell tumor(GCT) of bone is a commonly occurring, locally aggressive benign tumor which has high recurrence rate. GCT represents $5 \%$ of all primary bone tumors. In 1818, Cooper described GCTs first, later Nelaton showed that they can be locally aggressive and Virchow described their rarely malignant potential. ${ }^{1} \mathrm{GCT}$ is commonly seen in patients who are skeletally mature, between $20-45$ years. Although around $10 \%$ cases are seen in $2^{\text {nd }}$ decade of life. Slight female predominance is seen in literature. ${ }^{2}$ Any part of skeleton can be involved but there is a definite predilection for ends of long bones. The most common location for GCT as per their frequency are- distal end of femur, proximal end of tibia, distal end of radius, proximal humerus and vertebral body of sacrum. Epiphysis of long bones is the classic site of GCT. Along epiphysis, extension in metaphysis or diaphysis may be seen. Involvement of bones of hands, feet, jaw, vertebrae (other than sacrum) is unusual. ${ }^{3}$ Primary and recurrent GCT is typically benign. Malignant transformation is seen in $<1 \%$ of all cases and patients are a decade older than benign ones. ${ }^{4,5}$ Giant cell containing lesions in small bones are aneurysmal bone cysts or granulomas containing giant cells. However, rarely GCT in small bones of extremities do occur and are more aggressive in their behavior. ${ }^{6,7} \mathrm{In}$ young patients and in small bones of hands and feet, multicentric lesions have been reported. ${ }^{8,9} \mathrm{GCT}$ of tendon sheath (Tenosynovial GCT) are rare, generally benign slowly growing, intraarticular soft tissue tumors. They can be divided as localized and diffuse type. Clinically, GCT is generally painless swelling but can be painful due to mechanical insufficiency from bone destruction. GCT 
around joints limits the range of motion. Around $12 \%$ are associated with pathological fracture. These cases are thought to be of aggressive disease and high recurrence risk. ${ }^{11}$ An interesting thing noted in literature that almost all cases of metastases of GCT have occurred after surgical removal. There is a possibility that mechanical disruption of tumor and access to blood stream can lead to metastases. However, there is no relationship found between giant cells in blood stream and prognosis. (Ackerman2172)

\section{MATERIALS AND METHOD}

The present study was conducted from June 2017September 2019 in the department of Orthopedics of a tertiary care hospital. A total number of 20 cases of Giant Cell Tumors of bone and tendon sheath were studied in this duration. Clinical history and examination findings were studied from hospital record section. Information regarding the clinical data, radiological findings and site of the tumor was studied.

\section{RESULTS}

Total 20 cases of GCT were studied. Out of these, 15 cases were seen in bone and 5 cases in tendon sheath.

Most common site in the present study is distal end of femur. (Table 1)

Most common age group for GCT was 15-30 years. (Table 2)

Female predominance (12 cases) was noted in this study. In all GCT 1 year post-operative period was uneventful, no recurrence was found.

A 28 years old female was presented with swelling on knee. Radiological work-up was done (Figure 1) and diagnosis of GCT was made. Surgery- was done. A 20 years old male presented with progressively increasing, slightly painful giant swelling on calcaneus since 1 year. After X-ray and MRI (Figure 2), osteolytic lesion was noted. Probable diagnosis of GCT was made. Excision and curettage with bone grafting was performed. The diagnosis of GCT was confirmed after histopathological examination of curettage which showed characteristic multi nucleated giant cells and stromal mononuclear cells. Post-operative period was uneventful. Cases with GCT of tendon sheath (Figure 3and4) presented with very slowly growing painless swelling. After radiographic studies and Fine Needle Aspiration diagnosis of GCT made. After, surgical excision there was no recurrence of tumor over follow-up of 2 years. Most of the tendon sheath GCT were present of flexor tendons of phalanges.

Table 1: Distribution of GCT of bone according to site

\begin{tabular}{|c|c|}
\hline Site & Number of cases \\
\hline \multicolumn{2}{|l|}{ GCT of Bone } \\
\hline Distal end of femur & 6 \\
\hline Distal end of tibia & 4 \\
\hline Proximal end of radius & 4 \\
\hline Calcaneus & 1 \\
\hline \multicolumn{2}{|l|}{ GCT of Tendon Sheath } \\
\hline Proximal phalanx -Flexor tendon & 2 \\
\hline Distal Phalanx - Flexor tendon & 2 \\
\hline Ankle- Peroneal Tendon & 1 \\
\hline Total & 20 \\
\hline Age group $\mathrm{Nu}$ & iber of cases \\
\hline $15-30$ years & 16 \\
\hline $30-45$ years & 2 \\
\hline $45-60$ years & 2 \\
\hline
\end{tabular}

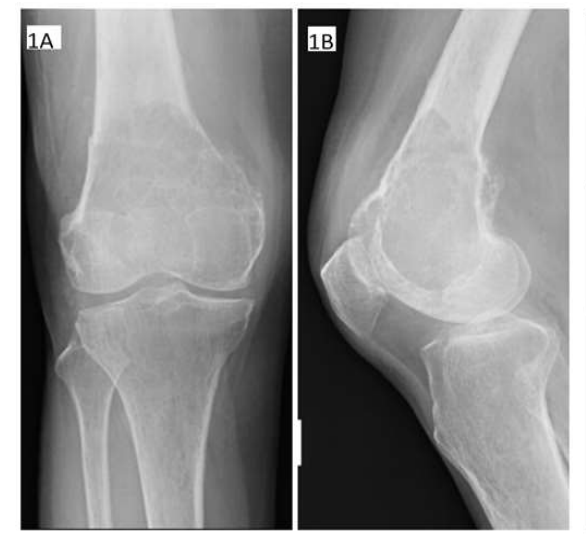

Figure 1

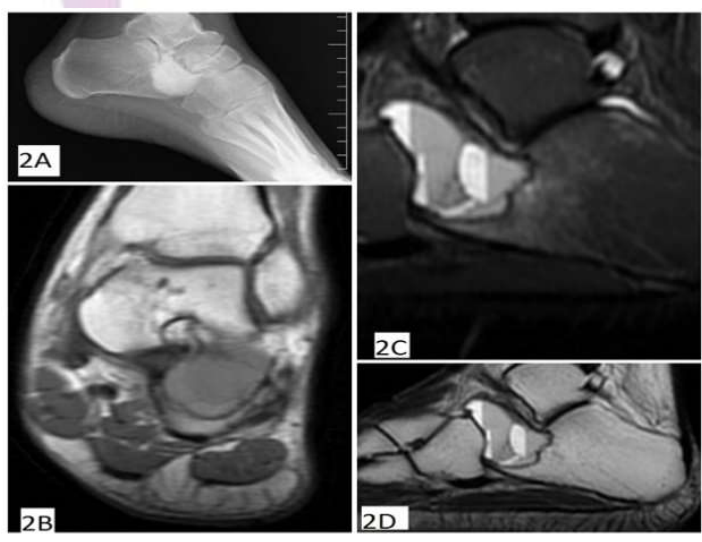

Figure 2

Figure 1: Xray AP and Lateral view of Right Knee: Distal end of femur shows an ill-defined lytic lesion with soap bubble appearance with thinning and destruction of cortex at a few places s/o GCT.

Figure 2: Well defined hyperintense lesion is noted in anterior process calcaneum on T2WI .It is hypointense T1WI and shows blood fluid levels within. It measures about $25 \times 31 \times 28 \mathrm{~mm}$ ( ML X AP X SI ). Scalloping and thinning of cortex seen. Adjacent marrow edema noted.Well defined lesion in anterior calcaneum with its morphology as described s/o GCT . 


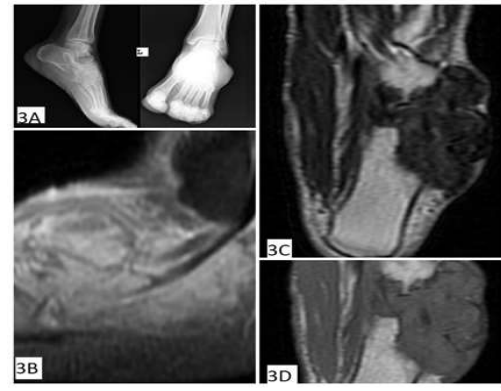

Figure 3

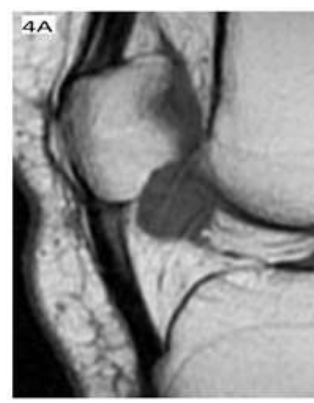

Figure 4

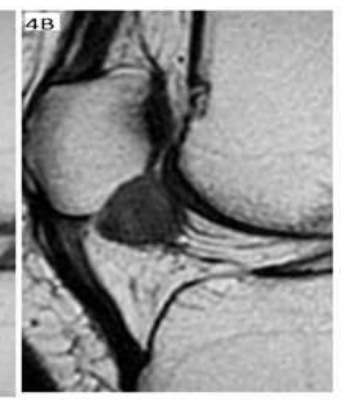

Figure 3: Lobulated lesion is noted along lateral aspect of mid foot bulging out in subcutaneous tissue. It is predominately hypointense on $\mathrm{T} 2 \mathrm{WI}$ and iso to hypointense on T1WI. Lesion is scalloping the cuboid and calcaneum and encasing peroneal tendon . Otherwise fat planes appear normal. Lesion measures about 61 × 33 × 46 mm (AP X ML X SI). Moderate heterogenous enhancement noted. Benign lesion- GCT of tendon; Figure 4: Well defined mixed intensity lesion infra patellar fat pad abutting patella and femur on MRI s/o Pigmented villonodular synovitis (PVNS) also known as intra-articular giant-cell tumor of the tendon sheath.

\section{DISCUSSION}

Typical epiphyseal location in long bones, female predominance (Male: Female - 1:1.5) as described in previous studies. Calcaneal GCT is very rare entity. Campanacci et al. reported only 2 cases of GCTcalcaneum out of 327 cases of all GCT. ${ }^{2}$ On X-ray, GCT of bone shows radiolucent, osteolytic, expansile lesion in the epiphyseal region (usually without periosteal reaction) is the characteristic appearance of typical GCT. Computed Tomography (CT) and Magnetic Resonance Imaging (MRI) are useful to confirm subchondral location and extent into soft tissue. GCT of tendon sheath shows no bone involvement and can be diagnosed on Fine needle aspiration. ${ }^{1}$ Treatment- surgical management included curettage with bone grafting or wide local excision with graft. To ensure adequate curettage and complete tumor removal, proper exposure of tumor is done by a large window in the cortex. The subchondral defects due to curettage was filled with use of bone grafts and cement. A minimum 1 year post-operative follow up was uneventful with no recurrence. Nowadays, local adjuvant radiotherapy may be done to control the recurrence. Extensive radiotherapy is reserved where surgical removal is impossible, malignant transformation of GCT cases and GCT of spine if is inaccessible. Osteo-clastic giant cells express Cytokine RANKL stimulated RANK receptor. So treatment with monoclonal antibodies like denosumab against them is one of the newer modes of treatment. ${ }^{12,13}$

\section{CONCLUSION}

GCT of bone and tendon sheath is typically benign tumor. Surgically excision with bone grafting and adjuvant therapy can cure the lesion. Follow-up after surgery is important to know about recurrences.

\section{REFERENCES}

1. Turcotte RE. Giant cell tumor of bone. Orthop Clin North Am. 2006; 37(1): 35-51.

2. Campanacci M, Giunti A, Olmi R. Giant-cell tumors of bone. A study of 209 cases with long term follow-up in 130. Ital J Orthop Traumatol 1975; 1: 249-277.

3. Savini R, Gherlinzoni F, Morandi M. Surgical treatment of giant cell tumor of the spine. Instituto Orthopedico Rizzoli. J Bone Joint Surg (Am) 1983; 65: 1283-1290.

4. Unni KK. How to diagnose malignant giant cell tumor. Pathol Case Rev. 2001; 6(1): 33-37.

5. Palmerini E, Picci $P$, Reichardt $P$, et al.. Malignancy of Giant Cell Tumor of Bone: A Review of the Literature. Technol Cancer Res Treat. 2019; 18: 1533033819840000.

6. Biscaglia R, Bacchini P, Bertoni F. Giant cell tumor of the bones of hand and foot. Cancer 2000; 88: 2022-2032.

7. Wold LE, Swee RG. Giant cell tumor of the small bones of the hands and feet. Semin Diagn Pathol 1994; 1: 173-184.

8. Hoch BL, Inwards C, Rosenberg AE. Multicentric Giant cell tumor of bone: a clinico-pathological analysis of thirty cases. Mod Pathol 2003; 16: 13-14.

9. Peimer CA, Schiller AL, Mankin HJ et al.. Multicentric giantcell tumor of bone. J Bone Joint Surg Am. 1980; 62: 652-656.

10. David R, Lucas MD. Tenosynovial Giant Cell Tumor. Arch Pathol Lab Med. 2012; 136: 901-906.

11. Jeys LM, Suneja R, Chami G, et al. Impending Fractures in giant cell tumors of the distal femur: incidence and outcome. Int Orthop. 2006; 30(20): 135-8.

12. Sobti A, Agrawal P, Agarwala S, et al.. Giant Cell Tumor of Bone- An Overview. Arch Bone Jt Surg. 2016; 4(1): 2-9.

13. McDonald DJ, Sim FH, McLeod RA. Giant cell tumor of bone. J Bone Joint Surg (Am) 1986; 68: 235-242.

\section{Source of Support: None Declared Conflict of Interest: None Declared}

Policy for Articles with Open Access:

Authors who publish with MedPulse International Journal of Orthopedics, (Print ISSN: 2579-0889, Online) (ISSN: 2636-4638) agree to the following terms: Authors retain copyright and grant the journal right of first publication with the work simultaneously licensed under a Creative Commons Attribution License that allows others to share the work with an acknowledgement of the work's authorship and initial publication in this journal.

Authors are permitted and encouraged to post links to their work online (e.g., in institutional repositories or on their website) prior to and during the submission process, as it can lead to productive exchanges, as well as earlier and greater citation of published work. 